\title{
THE METCRAX II FIELD EXPERIMENT \\ A Study of Downslope Windstorm-Type Flows in Arizona's Meteor Crater
}

\author{
by Manuela Lehner, C. David Whiteman, Sebastian W. Hoch, Erik T. Crosman, \\ Matthew E. Jeglum, Nihanth W. Cherukuru, Ronald Calhoun, Bianca Adler, Norbert Kalthoff, \\ Richard Rotunno, Thomas W. Horst, Steven Semmer, William O. J. Brown, Steven P. Oncley, \\ Roland Vogt, A. Martina Grudzielanek, Jan Cermak, Nils J. Fonteyne, Christian Bernhofer, \\ andrea Pitacco, and Petra Klein
}

The METCRAX II field investigation of downslope windstorm-type flows in Arizona's Meteor Crater is described along with first results from the analyses of the extensive dataset.

AfFiliations: Lehner, Whiteman, HOCH, CROSMAN, AND JeglumUniversity of Utah, Salt Lake City, Utah; CherUKURU AND CALHOUNArizona State University, Tempe, Arizona; Adler AND KalthoffKarlsruhe Institute of Technology, Karlsruhe, Germany; RotunNo, Horst, Semmer, Brown, ANd OnCley-National Center for Atmospheric Research, Boulder, Colorado; VoGT-University of Basel, Basel, Switzerland; Grudzielanek, Cermak, and Fonteyne-RuhrUniversität Bochum, Bochum, Germany; BerNHOFER-Technische Universität Dresden, Dresden, Germany; PITACCo—University of Padua, Padua, Italy; KLEIN—University of Oklahoma, Norman, Oklahoma
2008). On several nights during METCRAX I, high wind speeds and strong turbulence were encountered over the west sidewall, while the east sidewall and the crater center seemed to remain unaffected. At the same time, observed temperatures over the west sidewall were much higher than over the rest of the crater basin. Subsequent analysis revealed that these events are produced by the interaction of a southwesterly, mesoscale katabatic flow, which forms on the plain surrounding the crater during undisturbed, clear-sky
CORRESPONDING AUTHOR: Manuela Lehner, Department of Atmospheric Sciences, University of Utah, 135 S I460 E, Rm 819, Salt Lake City, UT 84II2-0II0

E-mail: manuela.lehner@utah.edu

The abstract for this article can be found in this issue, following the table of contents. DOI:10.1175/BAMS-D-14-00238.I

In final form 19 March 2015

(02016 American Meteorological Society 


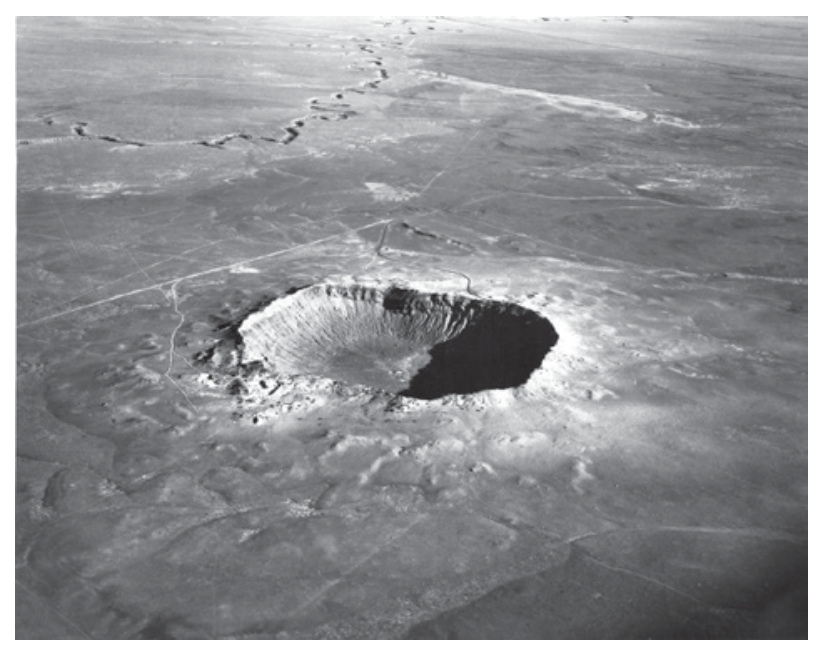

Fig. I. Aerial photograph of Arizona's Meteor Crater, looking north-northwest. Copyright J. S. Shelton; used with permission.

nights, with the crater topography (Adler et al. 2012). The flow across the crater topography produces a deep wave in the lee of the southwest crater rim, bringing warm air from aloft down into the crater basin above its southwest slope, while typically producing little disturbance to the stable air mass in other parts of the basin or to the shallow layer of cold air on the underlying slope. The downslope windstorm-type flows (DWFs), which could not be investigated in more detail with the limited data from METCRAX I, were the focus of the 2013 experiment. The phenomenon of interest occurs within a small spatial domain that could be studied by continuously monitoring the characteristics of the flow approaching the crater and the resulting flow transformations inside the crater. The continuous monitoring was accomplished using in situ and remote sensing instruments, supplemented by tethered balloons, radiosondes, and scanning Doppler lidars during nighttime intensive observational periods (IOPs).

The METCRAX II program (www.inscc.utah .edu/ whiteman/metcrax $2 /$ ) is a 4 -yr collaborative research program involving four principal investigators and their students and colleagues from different institutions in the United States and in Europe. Major field support was provided by the National Center for Atmospheric Research (NCAR)'s Earth Observing Laboratory (EOL; see sidebar on "Support from NCAR EOL"). Data from the field program are supporting basic meteorological analyses and model simulations to gain an improved understanding of forced flows over mountains in the simple topography of the Meteor Crater. This article provides an overview of the METCRAX II field program and presents some initial analyses. A number of research questions guided the planning of this experiment and governed the choices of field instrumentation and operating procedures. Selected research questions are listed in Table 1.

DOWNSLOPE WINDSTORMS. Downslope windstorms occur throughout the world in places with mountainous terrain, often producing strong and gusty winds that can pose a safety hazard and cause substantial damage to building structures (Bergen and Murphy 1978). Well-known downslope windstorms include the Alpine foehn (e.g., Mayr and Armi 2008; Richner and Hächler 2012), the Adriatic bora (e.g., Gohm et al. 2008; Grisogono and Belušić 2009), and the Rocky Mountain chinook or Boulder windstorm (e.g., Brinkmann 1974; Lilly 1978). Several large field campaigns have studied downslope windstorms, for example, in the Alps (Bougeault et al. 2001; Smith et al. 2007), the Pyrenees (Bougeault et al. 1993), and the Sierra Nevada (Grubišić et al. 2008). The theory of downslope windstorms has been the

TABLE I. Selected scientific questions.

-What are the controlling upstream parameters (e.g., inversion depth, stability, wind speed, and vertical wind shear) that cause DWFs to develop? How does a blocked flow layer upwind of the circular crater rim modify the flow? How much air is drawn from the upwind blocked layer as the flow goes over the rim? What meteorological mechanisms produce changes in the approach flow that tip the flow structure into a full-fledged DWF?

- Which of the existing theories on downslope windstorms can explain the DWFs at Meteor Crater?

- What is the three-dimensional structure of DWFs that develop behind the circular rim of Meteor Crater? How do these three-dimensional flows evolve and what are their characteristics and climatology? What intermediate changes in flow structure occur as the approach flow changes? How does the crater atmosphere respond to the warm-air intrusions associated with DWFs? What role does the downstream stability inside the crater play in determining the depth of flow penetration?

- Can existing mesoscale models produce accurate simulations of the evolution of DWFs at Meteor Crater and for other idealized basins and ridges of different size and shape? Will parametric studies with the models be successful in defining the parameter space in which such flows can be expected and assist in leading to improved understanding that will provide practical benefits for forecasting of DWF events? 


\section{SUPPORT FROM NCAR EOL}

METCRAX II would not have been possible without field support from the NCAR EOL, specifically its ISFS, ISS, and GAUS. NCAR staff deployed key equipment such as the scanning Doppler lidar on the north rim and the two fully instrumented 40- and 50-m towers (Fig. SBI). They also provided a wide variety of supporting observations, such as surface energy balance measurements. Quality-controlled data were made avail- able to the project scientists after the experiment, along with comprehensive metadata. See Table 3 for a complete list of equipment provided by NCAR.

The NCAR field participants were an integral part of the experimental team. Without their help, knowledge, and expertise, METCRAX II would not have been successful.

Examples of their activities that are normally not reflected in research articles include securing site access agreements and building permits for towers, designing and constructing tower anchors to avoid impacts to pristine geological features, and organizing an open house for the interested public. And as one of our team members summarizes: "When your generator stalls, you're a lucky man if you have the NCAR folks on your team...!"

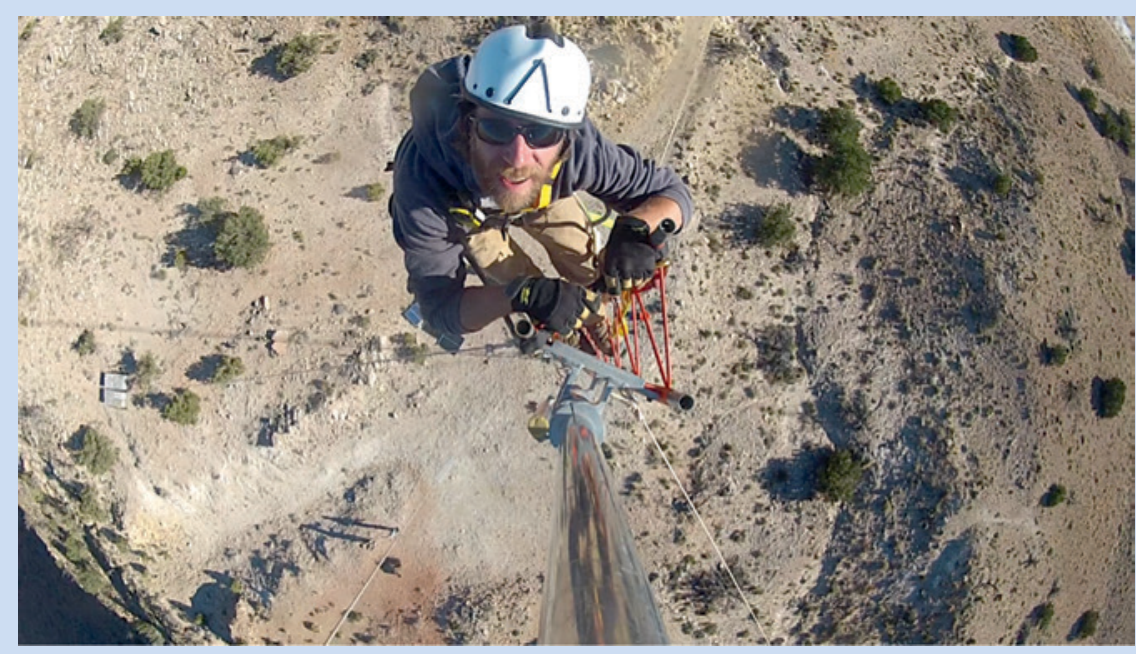

FIG. SBI. NCAR technician Chris Golubieski from ISFS during the construction of the 40-m mast on the south rim of the Meteor Crater. Photo courtesy of Tim Lim.

subject of numerous studies and is summarized in many review articles (Smith 1979, 1989; Durran 1990, 2003; Jackson et al. 2012).

Jackson et al. (2012) describe the three main mechanisms leading to downslope windstorms that have been suggested in the literature: 1) In the concept of hydraulic theory, which is based on an analogy between downslope windstorms and water flowing over obstacles, downslope windstorms occur as the flow transitions from subcritical (Froude number smaller than unity) upstream of a mountain ridge to supercritical (Froude number larger than unity) downstream of the ridge (Long 1954, 1955; Houghton and Kasahara 1968; Smith 1985). 2) Upward-propagating wave energy generated by the mountain is reflected downward at a critical layer producing wave amplification (Klemp and Lilly 1975). 3) Wave breaking produces a self-induced critical layer that reflects wave energy downward, causing wave amplification (Clark and Peltier 1977; Peltier and Clark 1979). Durran
(1986) and Durran and Klemp (1987) concluded that if a wave-trapping mechanism is present, hydraulic theory can successfully describe downslope windstorms.

Downslope windstorms occur not only on Earth but are also believed to occur in Martian craters (Magalhães and Young 1995). The large number of impact craters on Mars and their possible impact on dust transport and deposition has led to a number of studies on flow over craters (Greeley et al. 1974; Rafkin et al. 2001), including simulations for Earth's atmosphere (Soontiens et al. 2013). Following METCRAX I, numerical simulations of flow over the Meteor Crater have investigated seiche formation in the crater (Fritts et al. 2010) and flow modifications produced in the crater and downstream of the crater (Katurji et al. 2013).

THE METEOR CRATER. Arizona's Meteor Crater is a nearly circular bowl-shaped basin in northern Arizona (Fig. 1), which is located about $40 \mathrm{~km}$ east 
of Flagstaff on a large plain that rises slightly to the southwest, with a slope angle of approximately $1^{\circ}$. It was produced $49,000 \mathrm{yr}$ ago by the impact of a meteorite with a diameter of 40-50 m (Phillips et al. 1991; Kring 2007). The crater basin is approximately $1.2 \mathrm{~km}$ in diameter and $170 \mathrm{~m}$ in depth and is surrounded by a 30-50-m-high crater rim. The Meteor Crater and its surroundings are sparsely vegetated with grasses and small bushes. More information on the Meteor Crater, its geology, and vegetation can be found in Kring (2007) and Whiteman et al. (2008).

The small size of the Meteor Crater and the frequent occurrence of DWFs in the crater during clear-sky, undisturbed nights make it an ideal site for the study of downslope windstorms, as it can be extensively instrumented.

Downslope windstorm-type flows in the Meteor Crater. Adler et al. (2012) developed a conceptual model of DWF formation at the Meteor Crater based on the limited observations from METCRAX I (Fig. 2) that guided the design of the METCRAX II field campaign. On clear, undisturbed nights a mesoscale southwesterly drainage flow forms over the surrounding plain in connection with a shallow, surface-based inversion (Savage et al. 2008). The cold air produced by surface-cooling pools upstream of the southwest crater rim, where the terrain has a local low point. When the cold air reaches the top of the crater rim, it spills over the rim and drains into the crater basin as a shallow layer of cold air on the inner southwest sidewall that is much colder than the near-surface air on opposite sidewalls (Whiteman et al. 2010). The drainage of cold air into the basin was identified as the cause for the formation of a three-layer structure of the crater atmosphere, with a shallow but strong crater-floor inversion topped by a deep near-isothermal layer and a capping inversion near the top of the basin. A mass flux model successfully simulated this unusual temperature structure (Haiden et al. 2011), which was further investigated using numerical simulations by Kiefer and Zhong (2011).

Part of the southwesterly drainage winds on the adjacent plain split around the crater basin upstream of the blocked cold air, and part of it flows over the cold-air pool and the crater rim. Under certain conditions, a DWF event is produced above the inner southwest sidewall as the flow comes over the crater rim. It is one of the main research questions of METCRAX II to determine the exact conditions that lead to the formation of DWFs in the crater. During these events the flow descends into the crater following the underlying terrain to rebound somewhere along the sidewall, forming a wave in the lee of the crater rim and leaving the rest of the crater basin farther downstream mostly unaffected. The descending isentropes of the lee wave bring warm air down into the crater over the southwestern part, producing large horizontal temperature differences over a short distance between the southwestern part and the undisturbed crater atmosphere farther downstream. The descending flow over the sidewall is characterized by high wind speeds and increased turbulence. Analysis by Adler et al. (2012) found that the DWF events were intermittent in character with a mean duration of 13 min based on wind and pressure measurements on the lower west sidewall.

FIELD EXPERIMENT DESIGN. The experimental period ran from 30 September to 30 October 2013, identical to the experimental period of METCRAX I in October 2006. In northern Arizona, July-midSeptember is typically dominated by monsoonal
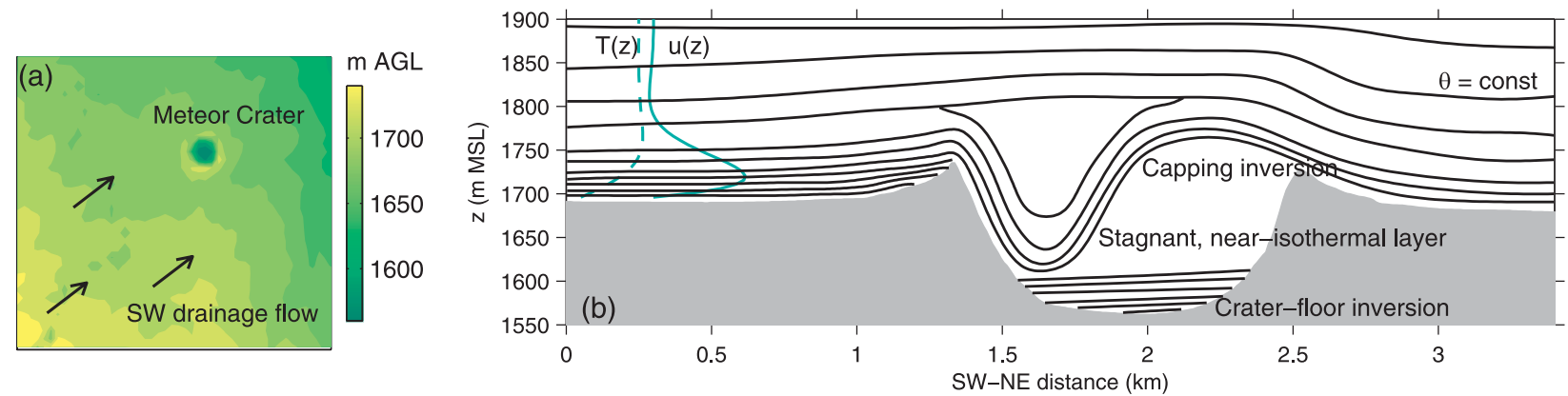

FIG. 2. Conceptual model of the formation of DWFs and warm-air intrusions in Arizona's Meteor Crater following Adler et al. (20I2). (a) A southwesterly drainage flow forms on the slightly sloping plain surrounding the Meteor Crater during clear-sky, undisturbed nights. (b) As the southwesterly drainage flow, with temperature and wind profiles $T(z)$ and $u(z)$, impinges on and flows over the crater rim, it can produce a wave in the lee of the southwest rim transporting warmer air from aloft down into the crater. 
conditions, whereas during October the conditions are more favorable for undisturbed, clear-sky nights, which allow the formation of terrain-induced flows. The 2013 monsoon was wetter and lasted longer than average in the area of the Meteor Crater. The monsoon ended in mid-September, with the excess moisture causing a major fall greenup in the crater and on the surrounding plains.

Prior to the field experiment, idealized model simulations were performed using the Cloud Model 1 (CM1; Bryan and Fritsch 2002) to guide the placement of instrumentation. For example, model simulations were used to determine the distance of flow blocking upstream of the crater basin to locate a site for upstream temperature and wind profile measurements where the flow is unaffected by the crater topography.

Deployment of instrumentation began in midSeptember. Because of the inaccessibility of the steep crater terrain, a helicopter was hired to transport equipment into the crater basin and to airlift concrete anchors for a 40-m meteorological tower to the crater rim. Inside the crater, the equipment then had to be distributed by foot, carrying it up or down the steep sidewalls. Strong winds during the second half of September interfered with the setup of the two large instrumented towers. The winds also destroyed a tent at the bottom of the crater, which was intended for equipment storage and for tethered balloon operations during IOPs and which had thus to be replaced prior to the start of the experiment. Because of these problems, not all of the instrumentation was operational by 30 September. However, most of the instruments were collecting data before the first IOP on 6 October.

Many of the instruments were operated continuously during the entire field campaign. The continuous measurements were supplemented with additional measurements conducted during seven overnight IOPs. Daily weather forecasts were issued to identify suitable nights of quiescent weather. IOPs started in the late afternoon, usually shortly before local sunset in the crater, after a group of field participants had hiked into the crater for an overnight stay. Tetheredballoon soundings, radiosonde launches, and lidar scans were made regularly throughout IOP nights until after the postsunrise breakup of the crater cold pool. Table 2 lists the seven IOPs with the times of the first and last tethered-balloon soundings in the crater, which mark the approximate beginning and end of the IOPs. IOP 6 was terminated slightly earlier than usual because of increasing cloud cover during the morning.

UPSTREAM INSTRUMENTATION. The field campaign was designed to continuously observe the wind and temperature profiles upstream of the crater while simultaneously monitoring the flow response within the crater basin. To this purpose, several remote and in situ surface and profiling instruments were deployed in and around the crater basin. A topographic map of the Meteor Crater and the METCRAX II measurement sites is shown in Fig. 3; Fig. 4 shows photographs of major equipment; and Table 3 lists the main measurement sites with their instrumentation, geographic coordinates, and terrain elevation.

Instrumented towers. The success of METCRAX II depended strongly on monitoring the approach flow upstream of the crater with high vertical and temporal resolution. To this purpose, two tall towers were erected by NCAR's Earth Observing Laboratory as part of their Integrated Surface Flux System (ISFS). A 50-mhigh tower was located approximately $1.6 \mathrm{~km}$ to the southwest of the Meteor Crater at NEAR (Figs. 3b, 4a) and a 40-m-high tower was located on the southwest

TABLE 2. METCRAX II intensive observational periods: dates of the IOPs, first and last tethered-balloon sounding inside the crater, and short synopsis.

\begin{tabular}{|ccccl|}
\hline IOP & Dates & $\begin{array}{l}\text { First sounding } \\
\text { time (MST) }\end{array}$ & $\begin{array}{l}\text { Last sounding } \\
\text { time (MST) }\end{array}$ & Synopsis \\
\hline 1 & $6-7$ Oct & 1737 & 0929 & Clear to 3/I0 Ci; weak DWF \\
\hline 2 & $11-12$ Oct & 1706 & 0943 & Clear; weak DWF \\
\hline 3 & $16-17$ Oct & 1510 & 0940 & Clear to I/I0 Ci; strong DWF \\
\hline 4 & $19-20$ Oct & 1551 & 0945 & Clear; strong DWF \\
\hline 5 & $21-22$ Oct & 1600 & 0944 & $\begin{array}{l}\text { Clear to I/I0 Ci; ambient north } \\
\text { flow prevented formation of deep } \\
\text { southwest drainage flow }\end{array}$ \\
\hline 6 & & & & 8/I0 Ci, Ac; weak DWF \\
\hline 7 & $23-24$ Oct & 1543 & 0827 & I//0-7/I0 Ci; weak DWF \\
\hline
\end{tabular}



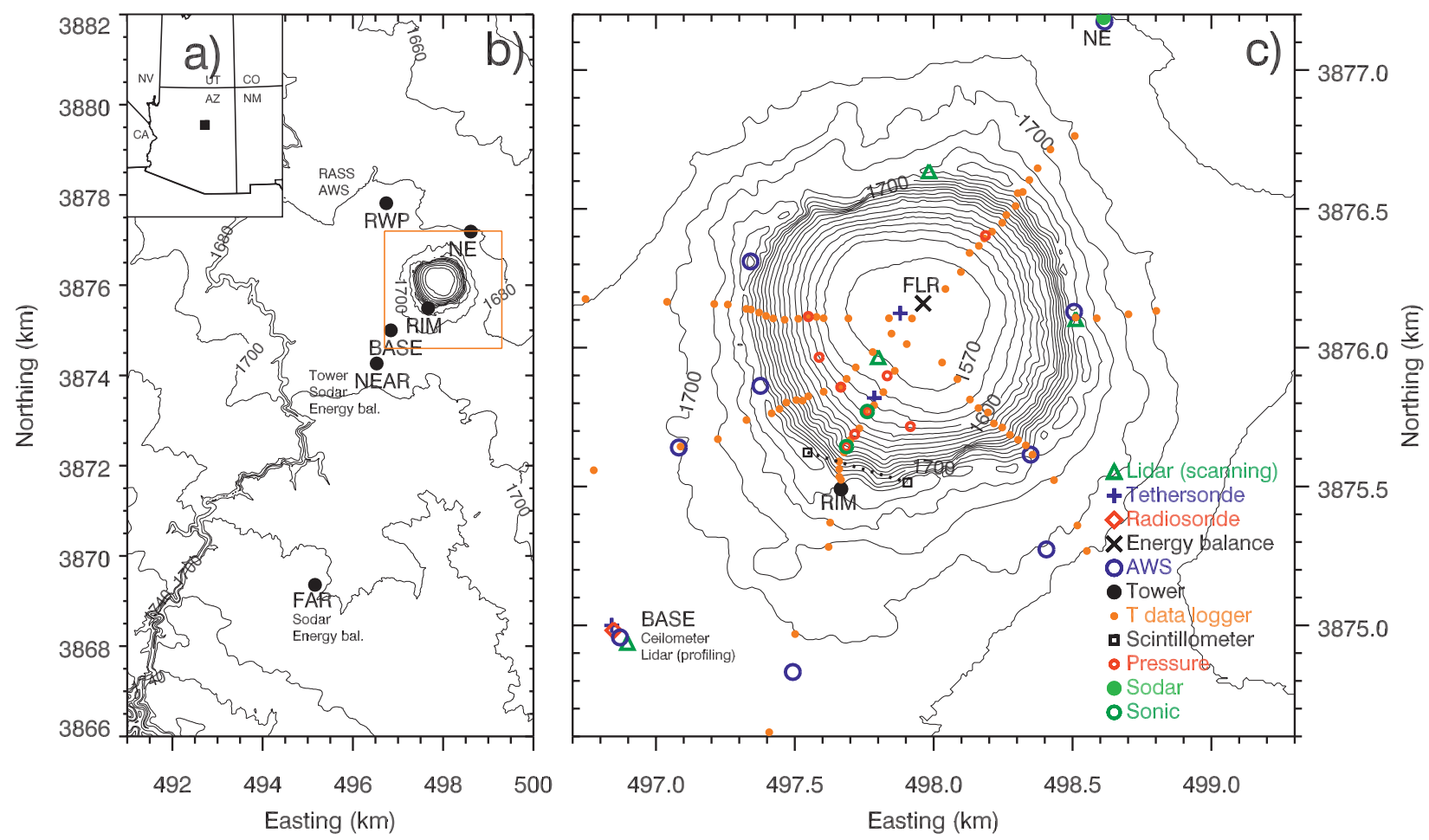

FIG. 3. (a) Location of the Meteor Crater in Arizona. (b) Map of the mesoscale plain surrounding the Meteor Crater and METCRAX II instrumentation sites. (c) Detailed map of the Meteor Crater topography and the locations of instrumentation inside the crater. Elevation contour intervals in (b) and (c) are 20 and 10 m, respectively.

crater rim at RIM (Figs. 3c, 4b). Both towers were instrumented with CSAT3 sonic anemometers and hygrothermometers at 5-m intervals to measure profiles of wind, temperature, and humidity and profiles of turbulent fluxes of momentum and sensible heat. Barometers were installed at the lowest tower levels, that is, at 3 and $5 \mathrm{~m}$ above ground level (AGL) at NEAR and RIM, respectively. A description of the sensors, sensor accuracy, calibration, and postprocessing procedures can be found at the ISFS METCRAX II website (www .eol.ucar.edu/content/isfs-metcraxii). The RIM site was located within a small pass in the crater's south rim. This site was expected to be favorable for the nocturnal southwesterly drainage flow to enter the crater basin.

Radiation and soil sensors were collocated with the 50-m tower at NEAR to provide the components of the radiation balance and the full surface energy budget. Pyranometers, measuring in- and outgoing shortwave radiation and diffuse radiation, and pyrgeometers, measuring ingoing and outgoing longwave radiation, were mounted on a sawhorse-type structure (Fig. 4c) next to the tower, together with a leaf wetness sensor. Subsurface observations included soil temperatures at $0.6,1.9,3.1$, and $4.4 \mathrm{~cm}$ and soil heat flux, moisture, thermal diffusivity, and thermal conductivity at $5 \mathrm{~cm}$ below the surface. A Krypton hygrometer was installed at the lowest tower level for latent heat flux calculation.
Remote sensing instrumentation. While the towers provided high vertical and temporal resolution of the upstream wind and temperature profiles, their observations were limited to the lowest layer of the atmosphere. To supplement the tower observations with measurements from higher above the surface, the Atmospheric Profiling Group at NCAR's Earth Observing Laboratory deployed their Integrated Sounding System (ISS) on the plain surrounding the Meteor Crater. Details on the deployed instrumentation can be found at the ISS METCRAX II website (www.eol .ucar.edu/content/apg-metcraxii). The ISS included a sodar-Radio Acoustic Sounding System (RASS) at NEAR next to the 50-m tower, which provided wind data from $40 \mathrm{~m}$ up to about $300 \mathrm{~m}$ AGL, with range gates every 15 m (Fig. 4d). A 449-MHz modular radar wind profiler and RASS were located to the northwest of the crater at site RWP (Figs. 3b, 4e).

The BASE site was located upstream between the crater rim and NEAR (Fig. 3b). In addition to housing the ISFS base trailer, where incoming data could be monitored in real time, two wind lidars provided additional information on the approach flow. A scanning Doppler lidar (Streamline, Halo Photonics, United Kingdom) was set up to perform a variety of scans during IOPs to observe the temporal evolution of the flow approaching the crater and its 


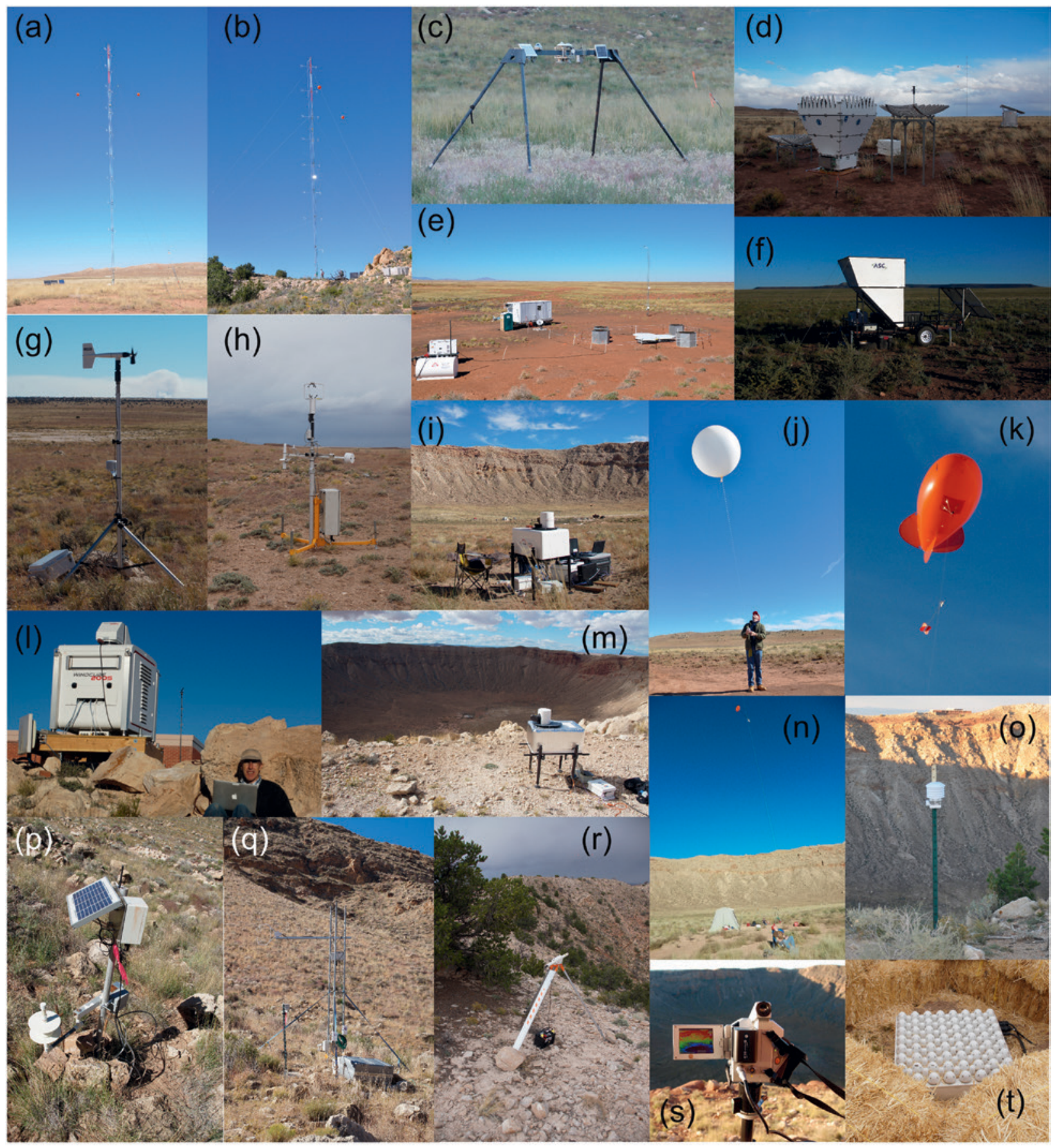

Fig. 4. Photographs of METCRAX II instrumentation. (a) 50-m tower at NEAR, (b) 40-m tower at RIM, (c) radiation balance station at FLR, (d) sodar at NEAR, (e) RWP-RASS at RWP, (f) sodar at FAR, (g),(h) surface weather stations, (i) lidar at the crater floor, (j) radiosonde, (k) tethersonde, (I) lidar at the north rim, (m) lidar at the east rim, (n) in-crater operations during IOPs, (o) HOBO temperature data-logger, (p) barometer on the inner crater sidewall, $(q)$ sonic anemometer on the southwest crater sidewall, $(r)$ scintillometer transmitter, (s) infrared camera, and $(t)$ sodar downstream of the crater basin. The locations of the instruments are shown in Fig. 3.

interaction with the crater topography. Depending on the conditions, a splitting of the flow around the crater topography or a flow over the crater rim could be observed. This lidar was installed before IOP 2 and moved from BASE to the east rim (Fig. 3c) before IOP 7 for additional coplanar scans with the scanning lidar at the crater floor (see below). The second Doppler lidar (WindCube, Leosphere, France) applied the velocity-azimuth display (VAD) scanning technique to provide vertical profiles of wind speed 


\begin{tabular}{|c|c|c|c|c|}
\hline \multicolumn{5}{|c|}{$\begin{array}{l}\text { TABLE 3. Longitude, latitude, altitude, and instrumentation of the main field sites. No coordinates are } \\
\text { given for the arrays of instruments listed in the last row, which were distributed over a larger area. } \\
\text { Coordinates in parentheses for the tethersonde site on the SW slope are for IOP I. The institutions } \\
\text { providing the instrumentation, indicated by an asterisk, and those operating it in the field, indicated } \\
\text { by a double asterisk, are listed in parentheses: Arizona State University (ASU), NCAR EOL GPS Ad- } \\
\text { vanced Upper-Air Sounding System (GAUS), InfraTec (IT), NCAR EOL Integrated Surface Flux Sys- } \\
\text { tem (ISFS), NCAR EOL Integrated Sounding System (ISS), Karlsruhe Institute of Technology (KIT), } \\
\text { University of Oklahoma (OU), Ruhr-Universität Bochum (RUB), Technische Universität Dresden } \\
\text { (TUD), University of Basel (UB), University of Padua (UP), and University of Utah (UU). }\end{array}$} \\
\hline Site & Lat $\left({ }^{\circ} \mathbf{N}\right)$ & Lon $\left({ }^{\circ} \mathrm{W}\right)$ & Alt (m MSL) & Instrumentation \\
\hline FAR & 34.967 & 111.053 & 1,724 & $\begin{array}{l}\text { Sodar (UU), 10-m meteorological tower } \\
\text { (ISFS), radiation balance station (ISFS), soil } \\
\text { sensors (ISFS) }\end{array}$ \\
\hline \multirow[t]{2}{*}{ NEAR } & 35.011 & 111.038 & 1,697 & $\begin{array}{l}\text { 50-m tower (ISFS), radiation balance sta- } \\
\text { tion (ISFS), soil sensors (ISFS) }\end{array}$ \\
\hline & 35.011 & 111.040 & 1,697 & Sodar (ISS) \\
\hline BASE & 35.017 & 111.034 & 1,695 & $\begin{array}{l}\text { Scanning lidar (OU,* ASU**), profiling lidar } \\
(\mathrm{KIT}) \text {, radiosonde (GAUS), tethersonde } \\
(\mathrm{KIT}), 10-\mathrm{m} \text { meteorological tower (ISFS), } \\
\text { ceilometer (ISS), sky cameras (ISS) }\end{array}$ \\
\hline RWP & 35.043 & 111.036 & 1,687 & $\begin{array}{l}\text { RWP/RASS (ISS), 10-m meteorological } \\
\text { tower (ISS) }\end{array}$ \\
\hline \multirow[t]{4}{*}{ RIM } & 35.022 & 111.026 & 1,733 & 40-m tower (ISFS) \\
\hline & 35.022 & 111.023 & 1,735 & Scintillometer transmitter (KIT) \\
\hline & 35.023 & III.027 & 1,750 & Scintillometer receiver (KIT) \\
\hline & 35.022 & 111.025 & 1,730 & IR camera (IT,* UB**, RUB**) \\
\hline \multirow[t]{6}{*}{ FLR } & 35.028 & 111.023 & 1,564 & $\begin{array}{l}\text { 10-m meteorological tower (ISFS), radia- } \\
\text { tion balance station (ISFS), soil sensors } \\
\text { (ISFS), tethersonde crater-floor (UU) }\end{array}$ \\
\hline & 35.026 & 111.024 & 1,572 & Scanning lidar (UU) \\
\hline & 35.025 & 111.024 & 1,590 & Tethersonde SW slope (UU) \\
\hline & $(35.026)$ & (III.024) & $(1,580)$ & \\
\hline & 35.025 & 111.025 & 1,600 & Two sonic anemometers (ISFS) \\
\hline & 35.023 & 111.025 & 1,653 & \\
\hline NRIM & 35.032 & III.022 & 1,723 & $\begin{array}{l}\text { Scanning lidar (ISS), } 2 \text { IR cameras (TUD,* } \\
\text { UP,* UB,** RUB**) }\end{array}$ \\
\hline ERIM & 35.028 & 111.016 & 1,725 & Scanning lidar (OU,* ASU**) \\
\hline NE & 35.037 & 111.015 & 1,681 & Sodar (KIT), surface weather station (KIT) \\
\hline Arrays & & & & $\begin{array}{l}\text { Surface weather stations (UU, KIT), barom- } \\
\text { eters (ISFS), temperature data-loggers (UU) }\end{array}$ \\
\hline
\end{tabular}

and direction below $600 \mathrm{~m}$ AGL. A ceilometer and sky cameras, which were installed at BASE as part of ISS, provided additional information on cloud coverage during the experiment.

To monitor the flow farther upstream of the crater, a minisodar was deployed approximately $6.5 \mathrm{~km}$ to the southwest of the crater at the FAR site (Figs. 3b, 4f) to measure winds at 10 -min intervals with 5 -m range gates. The FAR site was selected to detect disturbances in the nocturnal katabatic flow that may be produced upstream and transported downstream to the crater, where they could affect the formation of DWFs.

Surface weather stations. Four surface weather stations were deployed along the crater rim from westnorthwest to east (Fig. 3c) to monitor spatial variations in the flow coming over the crater rim. Three additional surface weather stations were deployed on 
the plain upstream of the crater to the west-southwest, southwest, and southeast. These additional weather stations were located at approximately the same elevation $[\approx 1,700 \mathrm{~m}$ above mean sea level (MSL)] to observe spatial variations in the cold-air pool that forms upstream of the crater rim and to observe the flow splitting around the crater topography. The surface weather stations (Figs. 4g-h) measured temperature and relative humidity at $1.2 \mathrm{~m}$ and wind at $2 \mathrm{~m}$ AGL. Two of the weather stations on the plain upstream of the crater included a pressure sensor and were instrumented with sonic anemometers for wind, momentum flux, and sensible heat flux measurements.

Ten-meter towers instrumented with wind sensors at $10 \mathrm{~m}$ AGL and temperature, humidity, and pressure sensors at $2 \mathrm{~m}$ AGL were installed at BASE, FAR, and RWP to provide additional data below the lowest range gates of the profiling instruments. A radiation and energy balance station identical to the one at NEAR (except without measuring diffuse radiation) was also installed at FAR, including a sonic anemometer and a hygrometer at $3 \mathrm{~m}$ AGL on the 10 -m tower.

Sounding systems. During IOPs, tethered balloon flights and 3-hourly radiosonde launches were made from BASE (Figs. 4j,k). Radiosondes from the NCAR GPS Advanced Upper-Air Sounding System (GAUS) were launched at 3-hourly intervals between 1600 and 1000 mountain standard time (MST) to observe background wind, temperature, and humidity above the near-surface layer. A tethersonde system was operated throughout IOP nights to monitor the development of upstream inversion and drainage flow conditions. The sonde, which measured pressure, temperature, dewpoint temperature, and wind, was attached to a tether line below a $5-\mathrm{m}^{3}$ balloon. The line was tethered to an electric winch, which was operated manually to make regular ascents. Ascents were made to heights of approximately $250 \mathrm{~m}$ AGL at approximately 15 -min intervals. After each ascent, the balloon was returned quickly to the ground and a new ascent was started almost immediately after, allowing the sonde to equilibrate at the ground for a short time.

\section{IN-CRATER INSTRUMENTATION. Scanning}

lidars. Two scanning Doppler wind lidars were installed to observe the flow within and above the crater basin. The first lidar, a Leosphere 200S (Leosphere, France) was leased by ISS and installed on the north rim, just to the west of the Crater Museum (Figs. 3c, 4l). The second lidar, a Streamline (Halo Photonics, United Kingdom), was helicoptered into the bottom of the crater basin
(Figs. 3c, 4i). The two lidars were positioned on a straight line between the north rim and the RIM site on the south rim. This orientation was chosen to allow coplanar scans in the direction of the anticipated approach flow. A dual-Doppler retrieval (Hill et al. 2010) can be applied to the dataset to resolve the two-dimensional wind field within the coplanar surface. Cherukuru et al. (2015) provide a detailed description of the dual-Doppler technique and its application during METCRAX-II. A suite of other range-height indicator (RHI) scans and plan position indicator (PPI) scans were used to evaluate the exact inflow direction of the DWFs and to study other phenomena such as cross-basin circulations during the morning and evening transition periods. The range gate length of the two lidars was varied between 18 and $24 \mathrm{~m}$ (Streamline) and between 25 and $50 \mathrm{~m}$ (200S) depending on aerosol loading and backscatter strength. The range of the two lidars varied greatly (from a few hundred meters to several kilometers) because of changes in atmospheric aerosol loading.

Tethered balloon soundings. A Vaisala Digicora Tethersonde System was used to fly two tethersondes in the crater basin during IOPs to probe the warm-air intrusions into the southwest part of the crater (Fig. 4n). One tethersonde was operated from the center of the crater floor and the second tethersonde was operated from the lower southwest sidewall (Fig. 3c), where the influence of warm-air intrusions was expected. The tethersonde site on the southwest sidewall was moved slightly up the slope after the first IOP because the initial site seemed to be too close to the downstream edge of the lee wave and warm-air intrusions. The tethersonde ascents were coordinated to ensure approximately the same altitude of the sondes at all times. Ascents were made to approximately $300 \mathrm{~m}$ above the crater floor and typically took 15-20 min. During strong warmair intrusion events, ascents were extended to the height where the two potential temperature profiles converged, that is, the maximum height from where the warm air over the southwest sidewall descended into the crater. The sondes measured pressure, temperature, relative humidity, and wind. A further description of wind measurements with this tethersonde system is given by Whiteman et al. (2008).

Surface temperature data-loggers. HOBO temperature data-loggers (Onset Computer, Inc., Bourne, Massachusetts) were installed along five lines running up the inner crater sidewalls and over the crater rim out onto the plain (Fig. 3c). The temperature loggers have been tested for meteorological applications and described by Whiteman et al. (2000). Four data-logger 
lines were deployed in the southwest part of the crater starting from a common center point at the crater floor to observe the spatial variations in the cold air draining down the sidewall. The fifth line was located on the opposite, northeast sidewall for comparison. An additional shorter east line ran down the outer east sidewall of the crater. Several of the data-loggers in the upper part of the crater sidewalls also included relative humidity sensors. The sensors were mounted at $1.2 \mathrm{~m} \mathrm{AGL}$ in solar radiation shields on fence posts (Fig. 4o). Instantaneous data values were recorded every $2.5 \mathrm{~min}$.

Barometer network. In the METCRAX I analysis by Adler et al. (2012), pressure data proved to be extremely useful in identifying warm-air intrusions. To observe the spatial variations in the warm-air intrusions over the southwest sidewall, 10 barometers were installed for METCRAX II in the crater basin (Figs. 3c, 4p). Four barometers were installed at 25 -m height intervals running up the south-southwest sidewall to determine the penetration depth and distance of the warm-air intrusions. To observe deviations from the south-southwest line to the west or south, four additional barometers were installed $50 \mathrm{~m}$ above the crater floor in the southwest quadrant of the crater. Two barometers at the crater floor and at $50 \mathrm{~m}$ above the crater floor on the northeast sidewall served as reference measurements, which were not affected by the warm-air intrusions.

Infrared time-lapse cameras. During IOPs 2-4, three infrared time-lapse cameras (Fig. 4s) were installed on the crater rim at RIM and on the north side next to the lidar. The cameras recorded surface temperatures of the opposing sidewalls at a high spatial resolution and a frequency of $0.5 \mathrm{~Hz}$. Changes in the recorded surface temperature field reflect the effects of near-surface air motions, including the drainage of cold air into the crater on the southwest sidewall and seiches of the crater-floor cold pool. Two additional cameras were moved between the north crater rim and BASE to take measurements of the plain downstream of the crater and of the outer upstream crater sidewall, respectively.

Additional in-crater instrumentation. For additional means of DWF identification, two sonic anemometers (Fig. 4q) were installed along the southwest sidewall 50 and $100 \mathrm{~m}$ above the crater floor (Fig. 3c) to observe increases in wind speed and turbulence during these events. In addition, a scintillometer was deployed to measure turbulence in the lee of the southwest crater rim. To that purpose, the transmitter (Fig. 4r) was placed on the crater rim to the east of RIM and the receiver to the west so that the scintillometer path formed a transect across the crater where the flow descends into the basin (Fig. 3c).

A 10-m meteorological tower and an energy balance station were installed at the crater floor (Fig. 3c) for comparison with outside conditions. Radiation balance and soil measurements were identical to those at the NEAR site. The 10-m tower was instrumented with temperature and relative humidity sensors at $2 \mathrm{~m}$ AGL and wind at $10 \mathrm{~m}$ AGL and a sonic anemometer and hygrometer at $3 \mathrm{~m}$ AGL for the calculation of turbulent fluxes.

DOWNSTREAM OBSERVATIONS. While the main focus of METCRAX II was on the flow upstream and inside the crater basin, the lee side of the crater basin was instrumented to study the possible occurrence of wakes behind the crater. To this purpose, a sodar (Fig. 4t) and a surface weather station measuring temperature, relative humidity, pressure, and wind were deployed approximately $700 \mathrm{~m}$ to the northeast of the crater basin (Fig. 3c). Data from these instruments are being used to study differences between the upstream and downstream thermal and flow conditions.

INITIAL ANALYSIS AND RESULTS. IOP overview. Consistent with the climatological expectations, October 2013 provided a mix of quiescent and synoptically forced flows. For the first half of October, the general synoptic pattern was progressive, with frequent trough passages. While largely or completely dry in northern Arizona, these storms nonetheless produced significant winds that precluded IOPs. IOPs 1 and 2 were conducted on 6-7 and 11-12 October during brief periods of shortwave ridging between the troughs. On 10 October, a particularly vigorous trough brought $5.7 \mathrm{~mm}$ of rain along with wind gusts of up to $28 \mathrm{~m} \mathrm{~s}^{-1}$ on the crater rim. This was the only measurable precipitation during the month. The large-scale pattern changed dramatically in mid-October as a blocking ridge off the Pacific coast brought generally clear and calm weather to Arizona. The remaining five IOPs were conducted under the influence of this ridge between 16 and 27 October. On 27 October, a strong trough, digging south out of the Pacific Northwest, brought strong southwesterly winds to the Meteor Crater. Unsettled weather associated with the trough continued through the end of the experiment on 30 October.

Strong DWF cases (IOP 3-4). The most pronounced DWFs and strongest warm-air intrusions occurred during IOPs 3 and 4 and lasted for a large part of the 
night (Fig. 5). These IOPs were different from the previous two IOPs and from subsequent IOPs, during which only comparatively weak DWF events were registered. Vertically integrated temperature differences between the southwest and center tethersondes below $200 \mathrm{~m}$ AGL, as a measure of warm-air intrusion strength, exceeded $500 \mathrm{Km}$ in some soundings (Figs. 5c,d). During both IOPs the southwesterly drainage flow over the surrounding plain at NEAR was comparatively deep and strong with wind speeds of $5 \mathrm{~m} \mathrm{~s}^{-1}$ or more at the top of the 50-m tower. Wind profiles from lidar VAD scans at BASE show that during both IOPs the wind direction was southwesterly to southeasterly within at least the lowest $300 \mathrm{~m}$, producing little directional wind shear in the approach flow (Fig. 6). An example of pronounced lee waves and strong warm-air intrusions during IOP 4 is shown below (Figs. 7-10).

Weak DWF cases (IOPs I-2 and 6-7). During four IOPs, only weak DWFs developed compared to IOP 3 and IOP 4 . The weakest and fewest warm-air intrusions were observed during IOP 1. During this IOP, however, the tethersonde on the southwest sidewall was operated farther down the slope than during subsequent IOPs so that it may have missed some of the weaker lee waves. The first two IOPs were conducted under clear-sky conditions similar to IOPs 3 and 4 , with only a few cirrus clouds present after sunrise in the morning of IOP 1 (Table 2). While a southwesterly drainage flow developed during both IOPs with jet maximum wind speeds of $5 \mathrm{~m} \mathrm{~s}^{-1}$ or more, wind speeds at the top of the 50- and 40-m towers were generally weaker than during IOPs 3 and 4 , indicating a comparatively shallow katabatic flow. The surfacebased inversion over the plain, as expressed by the temperature difference between the 50 - and 3-m tower levels at NEAR, was slightly stronger during IOP 1 compared to subsequent IOPs, while the transition to a southwesterly drainage flow was somewhat delayed during IOP 2 (Figs. 5a,b). Wind speeds increased after 2300 MST of IOP 2, leading to somewhat stronger DWFs, although not comparable to those observed during IOPs 3 and 4 . The last two IOPs at the end of the month (IOPs 6 and 7) were similar to IOPs 1 and 2 , with low wind speeds at the top of the towers. In contrast to previous IOPs, however, the last two IOPs were relatively cloudy, with up to $8 / 10$ cirrus coverage and some altocumulus clouds (Table 2). In addition, directional wind shear was high upstream of the crater during IOP 6, when the flow above the shallow drainage flow turned to a northerly direction (Fig. 6), which

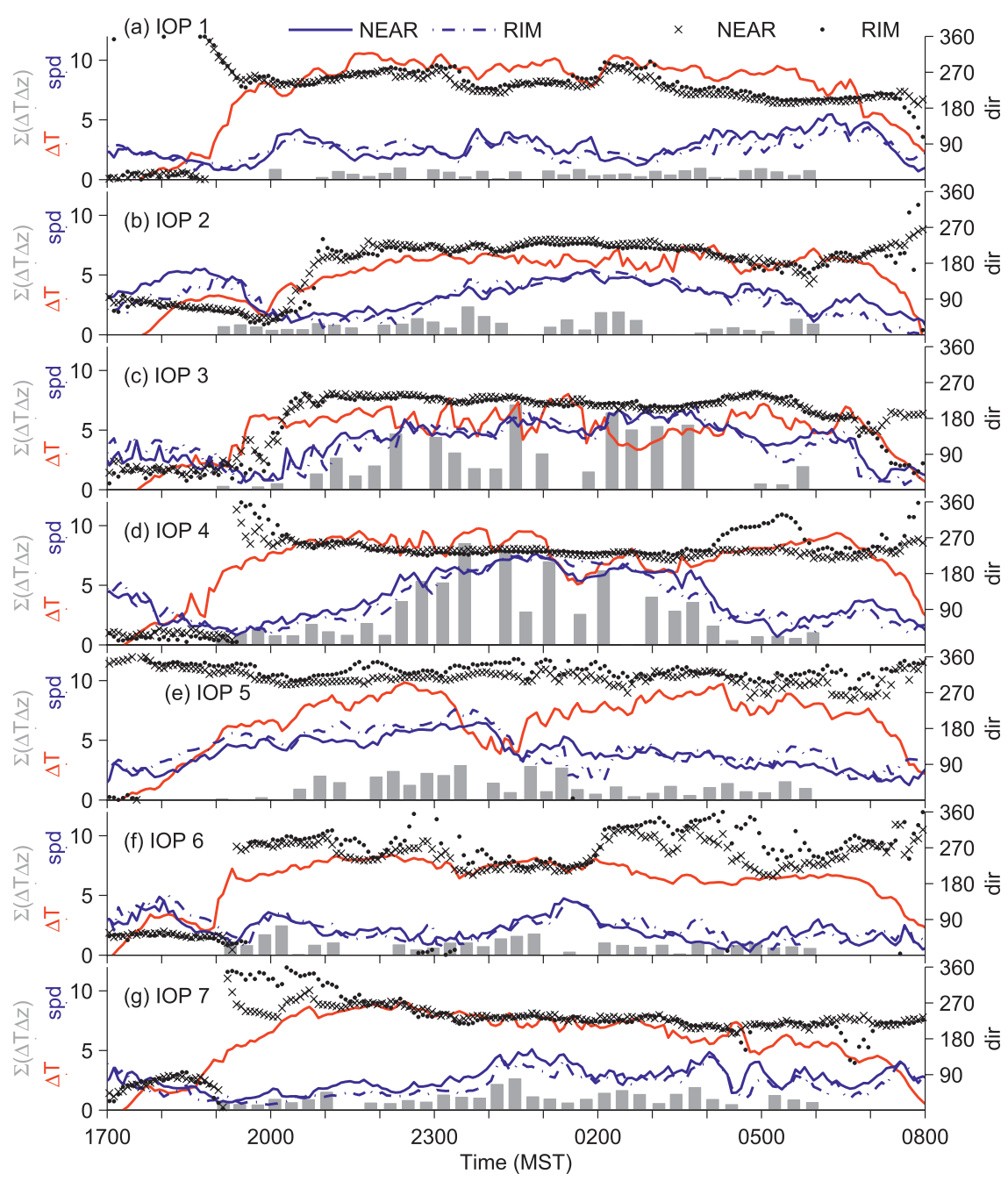

FIG. 5. Overview of the IOPs. Vertically integrated temperature difference $\left(10^{2} \mathrm{~K} \mathrm{~m}\right.$; gray bars) between the southwest and center tethersondes below $200 \mathrm{~m} \mathrm{AGL}$; temperature difference ( ${ }^{\circ} \mathrm{C}$; red) between 50 and $3 \mathrm{~m} \mathrm{AGL}$ at $\operatorname{NEAR}\left(\Delta T=T_{50}-T_{3}\right)$; and wind speed ( $\mathrm{m} \mathrm{s}^{-1}$; blue) and wind direction ( ${ }^{\circ}$; black; right axes) at NEAR (50 $\mathrm{m} \mathrm{AGL)}$ and RIM (40 $\mathrm{m} \mathrm{AGL).}$ 

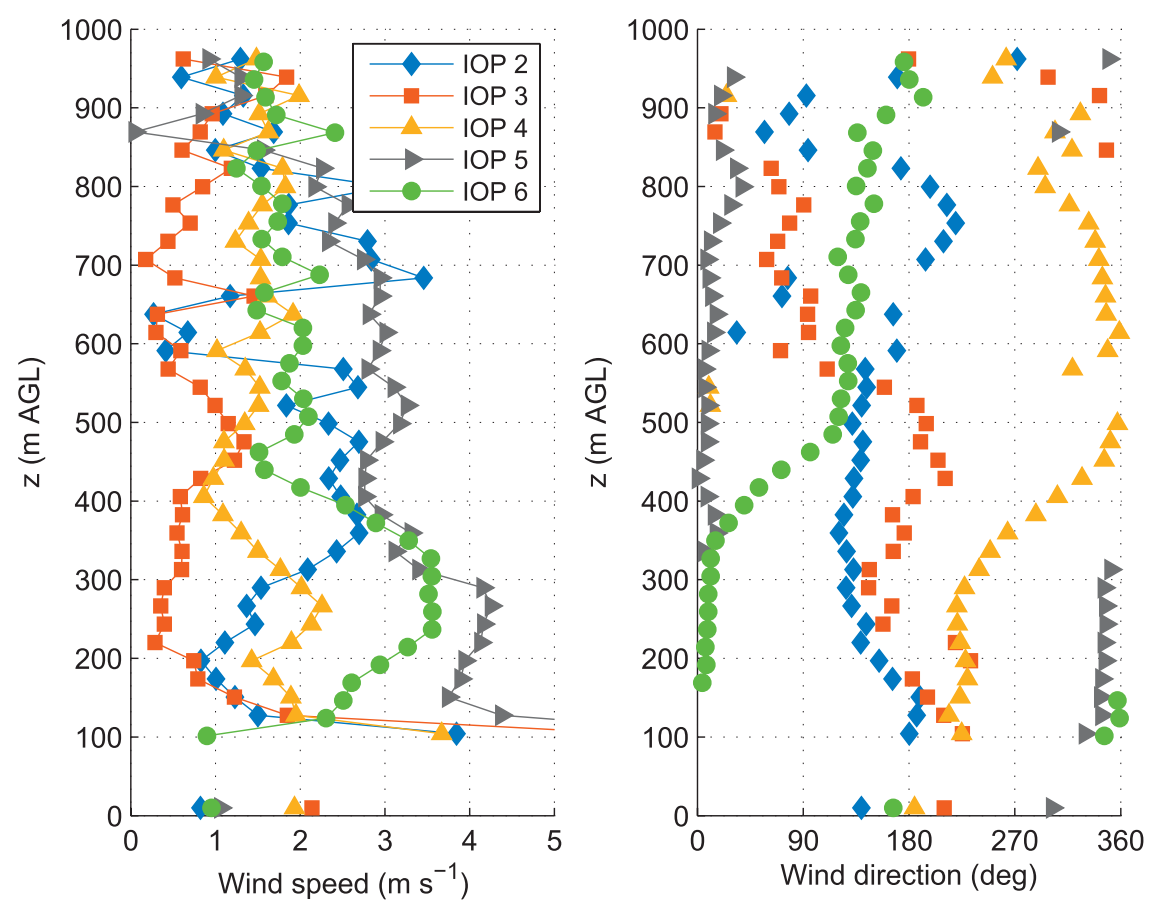

IOPs that displayed strong DWFs. After the onset of surface cooling over the plain, the inversion grew continuously in depth, gradually encompassing the HOBO temperature data-loggers along the outer south-southwest sidewall (Fig. 7a). The top of the inversion reached the crater rim around 2000 MST, indicated by a temperature drop at the lowest tower level at RIM. As the inversion continued to grow, it finally reached to approximately the top of the 40-m RIM tower, where the temperature remained much warmer. By 1930 MST, a weak and shallow drainage flow had developed at NEAR, which also grew in depth and strength (Fig. 7b). At 2000 MST a weak jet pro-

even reached down to the top of the NEAR and RIM towers during the second half of the night producing a westerly to northwesterly flow (Fig. 5).

Ambient wind case (IOP 5). Although clear-sky conditions prevailed during IOP 5 (Table 2) and a relatively strong surface-based inversion developed at NEAR (Fig. 5e), a strong northerly flow above the surface (Fig. 6) prevented the formation of a deep southwesterly drainage flow. At $10 \mathrm{~m}$ AGL at NEAR, a southwesterly downslope flow developed in the evening, but the winds turned to a northwesterly direction at $50 \mathrm{~m}$ AGL. The northwesterly flow also dominated at RIM, indicating an outflow through the southwest gap. The vertically integrated temperature difference between the two tethersondes shows warmer air over the southwest part of the crater during most of the night, but considering the background wind direction above the crater rim, this temperature difference cannot be explained by a DWF formation over the southwest sidewall.

Upstream conditions. In the following, the evening development of the upstream surface-based inversion and drainage flow that then leads to the development of DWFs in the crater is summarized using IOP 4 as an example (Fig. 7), as it was one of the two file was present at RIM. The drainage flow at NEAR eventually reached maximum wind speeds exceeding $5 \mathrm{~m} \mathrm{~s}^{-1}$ and by 2300 MST the height of the jet maximum had reached elevations close to rim height. In addition, wind speeds above the jet maximum also increased to about $3 \mathrm{~m} \mathrm{~s}^{-1}$. At this time, pronounced DWFs started to be observed in the crater.

Downslope windstorm-type flows. By the time that the upstream inversion forming outside the crater had grown to reach the crater rim (2000 MST), a strong, approximately 30 -m-deep surface-based inversion had developed within the crater basin (Fig. 8). The cold air on the southwest rim, which was much colder than the air over the rest of the crater at this elevation, drained into the crater along the southwest sidewall as previously reported by Whiteman et al. (2010). This shallow layer of air, colder than over the opposite sidewall and with a close-to-adiabatic stratification, was observed in the near-surface temperatures measured by the HOBO lines running up the west to south-southwest sidewalls (Fig. 8). This process of cold-air inflows was shown to lead to a thermal three-layer structure in the crater (Haiden et al. 2011). The development of a nearisothermal layer above the surface-based inversion and a weak capping inversion at rim level can be seen in Fig. 8. During the time of cold-air inflows, the southwest 

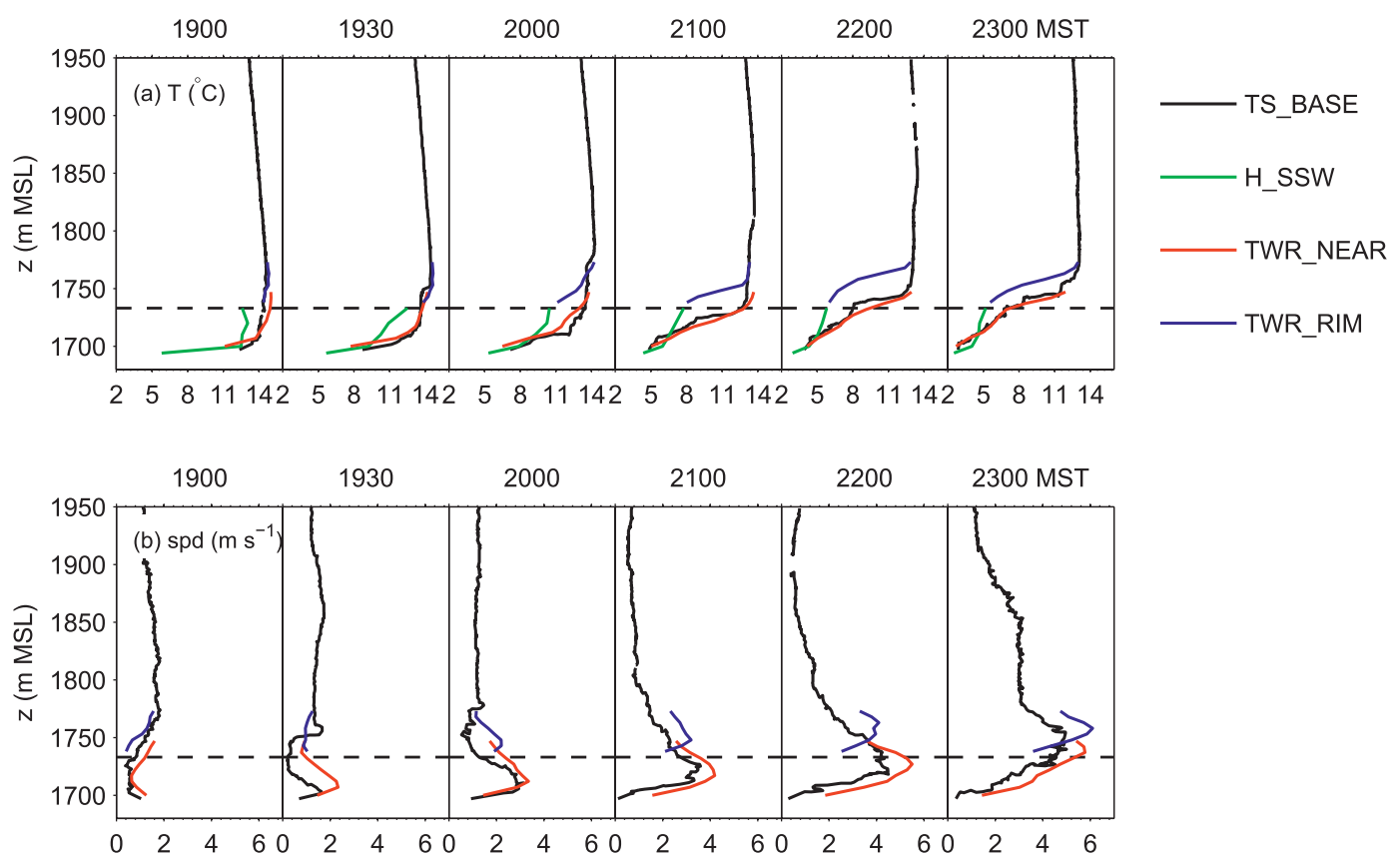

FIG. 7. Vertical profiles of (a) temperature and (b) wind speed on the plain upstream of the Meteor Crater between 1900 and 2300 MST 19 Oct (IOP 4). Data are from the tethersonde at BASE (TS_BASE), HOBO temperature data-loggers along the outer south-southwest sidewall (H_SSW), and the towers at NEAR and RIM (TWR_NEAR and TWR_RIM). HOBO and tower data are averaged over a I5-min period preceding the times indicated above each plot; tethered balloon soundings are from within this 15 -min window. The horizontal, black dashed line indicates the elevation of the gap in the southwest crater rim (location of the 40-m tower).

tethersonde profile was slightly warmer than the rest of the crater basin in the lowest $50 \mathrm{~m}$ above the basinfloor inversion. The current hypothesis is that this weak warming seen in the southwest tethersoundings is connected to the sudden onset of cold-air drainage into the crater along the southwest sidewall.

At 2230 MST, warm-air intrusions were clearly present over the southwest sidewall. The southwest sounding was about $4^{\circ} \mathrm{C}$ warmer than the sounding over the crater center in the lower part of the crater, with the air originating from an elevation above the capping inversion, where all three tethersonde profiles converged. The shallow inversion at the bottom of the warm-air intrusions marks the depth to which the lee wave penetrated into the crater. It reached down to about $50 \mathrm{~m}$ above the crater floor, that is, about $35 \mathrm{~m}$ above the top of the crater-floor inversion. The warm-air intrusion over the southwest

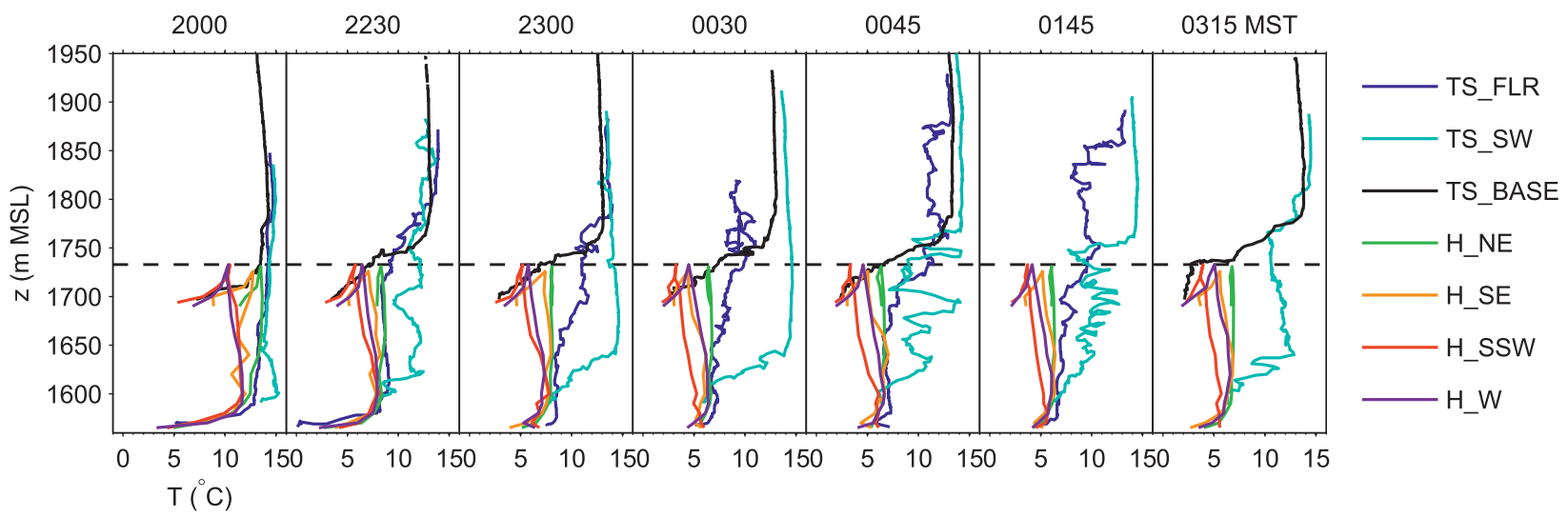

FIG. 8. Vertical temperature profiles from tethered balloon soundings (TS) and along-slope temperature profiles from HOBO lines $(\mathrm{H})$ during IOP 4 . HOBO data are averaged over a 15 -min period ending at the times indicated above each plot; tethered balloon soundings are from within this I5-min window. No tethered balloon soundings from BASE and FLR are available for 0145 and 0315 MST, respectively. 
part of the crater was also registered by the barometer network, through a decrease in the pressure over the southwest sidewall compared to the northeast sidewall (Fig. 9). At the same time, the DWF caused an increase in wind speed over the southwest crater sidewall. The strength of the warm-air intrusions increased to about $6^{\circ} \mathrm{C}$ in the lower part of the crater at $2300 \mathrm{MST}$ because of the air being mixed down from slightly higher aloft (Fig. 8).

The dual-Doppler lidar scans in the southsouthwest-north-northeast vertical scanning plane visualized the wave in the lee of the southwest crater rim. An example is shown in Fig. 10 for 2335 MST. At this time, the lidar-derived wind field agrees well with the previously developed conceptual model in that the flow coming over the crater rim descended in the lee following the underlying terrain. It rebounded near the location of the southwest tethersonde site and returned approximately to its ambient height above the crater. The area of strong winds remained relatively confined, with comparatively weak wind speeds above the descending flow and quiescent conditions in the center of the crater basin below the wave crest.

At 0030 MST, the southwest tethersonde sounding was more than $7^{\circ} \mathrm{C}$ warmer than the rest of the crater (Fig. 8), and even above the crater rim it was slightly warmer than the sounding over the crater center, indicating a higher origin of the warm-air intrusions and thus a deeper lee wave. Only $15 \mathrm{~min}$ later, the southwest temperature profiles had become extremely variable with height. Temperature changes of $7^{\circ} \mathrm{C}$ occurred over approximately $15 \mathrm{~m}$. This shows that the tethersonde was moving in and out of the warm region during its ascent, crossing the descending isentropes. This can be caused either by horizontal movements of the tethered balloon because of strong winds and turbulence or by a smaller lee wave so that the ascending branch of the wave was located over the tethersonde site. Lidar wind fields (Fig. 10) and a dropping pressure difference between the northeast and lower southwest sidewalls (Fig. 9) clearly point to the latter explanation. The pressure difference between the northeast and lower southwest sidewalls and the wind speed at the lower sidewall varied greatly between 2200 and 0330 MST (Fig. 9). The pressure difference between the northeast and upper southwest sidewalls remained comparatively constant and was mostly smaller than the difference between the northeast and lower southwest sidewall. This is an indication that the lee wave and warm-air intrusions weakened intermittently and retreated up the slope, where they were still registered by the barometer on the upper sidewall. This may explain the intermittent character of the DWFs observed by Adler et al. (2012) based on measurements on the lower sidewalls.

Downstream conditions. Downstream of the crater basin, the near-surface temperature remained more than $4^{\circ} \mathrm{C}$ warmer than the temperature on the upstream side during the night of IOP 4 (Fig. 11). This implies that a weaker surface inversion became established downstream of the crater, assuming similar conditions at the inversion top. A southwesterly drainage flow evolved near the surface reaching about $2 \mathrm{~m} \mathrm{~s}^{-1}$ at 1900 MST (Fig. 11); thus, its onset occurred slightly earlier than on the upstream side. Between about 2230 and $0330 \mathrm{MST}$, that is, during the period when DWFs were observed in the crater, gusty winds of up to $4 \mathrm{~m} \mathrm{~s}^{-1}$ and strong turbulence were evident near the surface

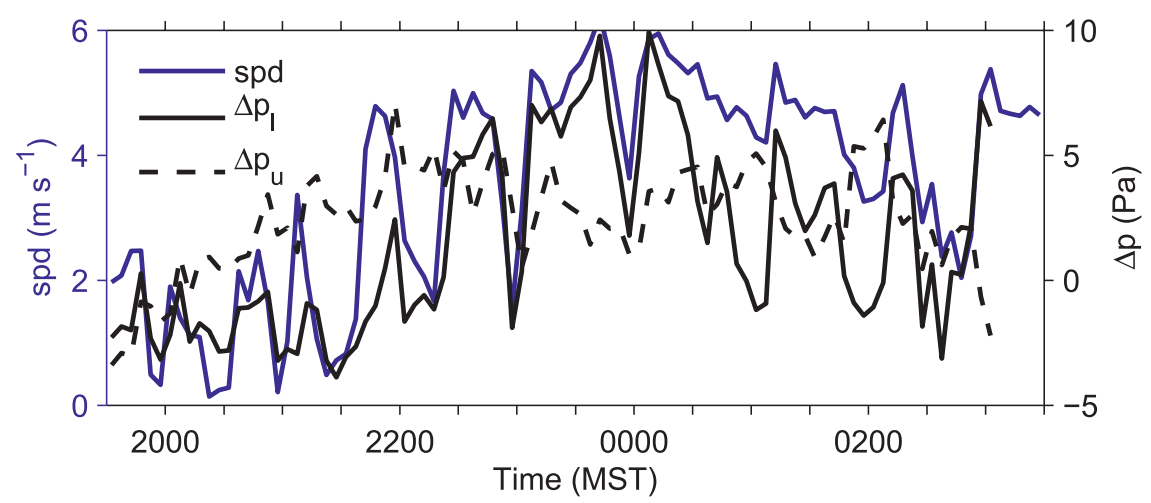

Fig. 9. Time series of wind speed on the southwest sidewall and pressure differences between the northeast sidewall and two sites on the southwest sidewall at 35 and $90 \mathrm{~m}$ above the crater floor during IOP $4\left(\Delta p_{1}=p_{\mathrm{NE}}-p_{\mathrm{SW} 35}\right.$ and $\left.\Delta p_{\mathrm{u}}=p_{\mathrm{NE}}-p_{\mathrm{sW} 90}\right)$. Pressure time series were filtered using a I-h running mean before calculating differences. Wind speed is from a sonic anemometer that was collocated with the barometer at the lower of the two sites on the southwest sidewall ( $35 \mathrm{~m}$ above the crater floor). downstream of the crater basin. Simultaneously, the flow accelerated at higher elevations and turned from westerly to southwesterly. The wind speed maximum of about $6 \mathrm{~m} \mathrm{~s}^{-1}$ occurred between about 30 and $50 \mathrm{~m}$ AGL, which approximately agreed with the upstream drainage flow characteristics. Thus, the flow field on the downstream side resembled the drainage flow on the plain upstream of the crater basin. After around 0330 MST, the mean wind speed decreased and gained a northerly component with 
increasing height. At the same time, turbulent kinetic energy near the surface increased. The reasons for this decrease in wind speed and increase in turbulent kinetic energy are not yet understood. The results, however, indicate a strong relation between the upstream drainage flow characteristics, the occurrence of DWFs in the crater, and the flow characteristics downstream of the crater basin.

Seiches. Oscillations were frequently observed in the near-surface temperatures along the lower crater sidewalls. The oscillations typically had periods of 15-20 min and were most pronounced in the lower part of the crater (Fig. 12). A direct comparison of the filtered temperature time series from the northeast and south-southwest sidewalls shows that the oscillations have phase shifts of about $180^{\circ}$; that is, a cooling on the northeast sidewall is accompanied by a warming on the south-southwest sidewall and vice versa. The phase shift suggests a sloshing of the crater-floor cold pool, which would also explain the strongest oscillations above the crater floor where vertical temperature gradients are strongest and vertical displacement would thus cause strongest temperature variations. The sloshing of the surface inversion was visualized by the infrared cameras on the crater rim (Fig. 13). A comparison of the ground temperature in the images at 2130 and 2140 MST shows the inversion moving up the southwest crater sidewall within this 10 -min period. The cause of the seiche formation, however, needs further investigation. Oscillations with similar periods were also present in temperature and wind observations at RIM and NEAR, which could be connected to the seiches inside the crater. Fritts et al. (2010) observed seiche formation in their simulations for an idealized crater basin, when the ambient flow over the crater was oscillatory.
SUMMARY AND OUTLOOK. The second Meteor Crater Experiment (METCRAX II) was designed to study the nocturnal occurrence of downslope windstorm-type flows (DWFs) in the Meteor Crater basin. DWFs are produced in the lee of the southwest crater rim as a southwesterly mesoscale drainage flow, which forms over the slightly sloping surrounding plain, flows over the rim. As the flow descends into the crater basin it brings down warmer air from aloft, causing warm-air intrusions over the southwest part of the crater, which can be observed in temperature soundings and surface pressure measurements. During METCRAX II, field equipment was placed inside and upstream of the crater basin to monitor the nocturnal development of the surface-based inversion and drainage flow over the surrounding plain together with the temperature and flow field within the crater. Data were collected for 1 month during October 2013 


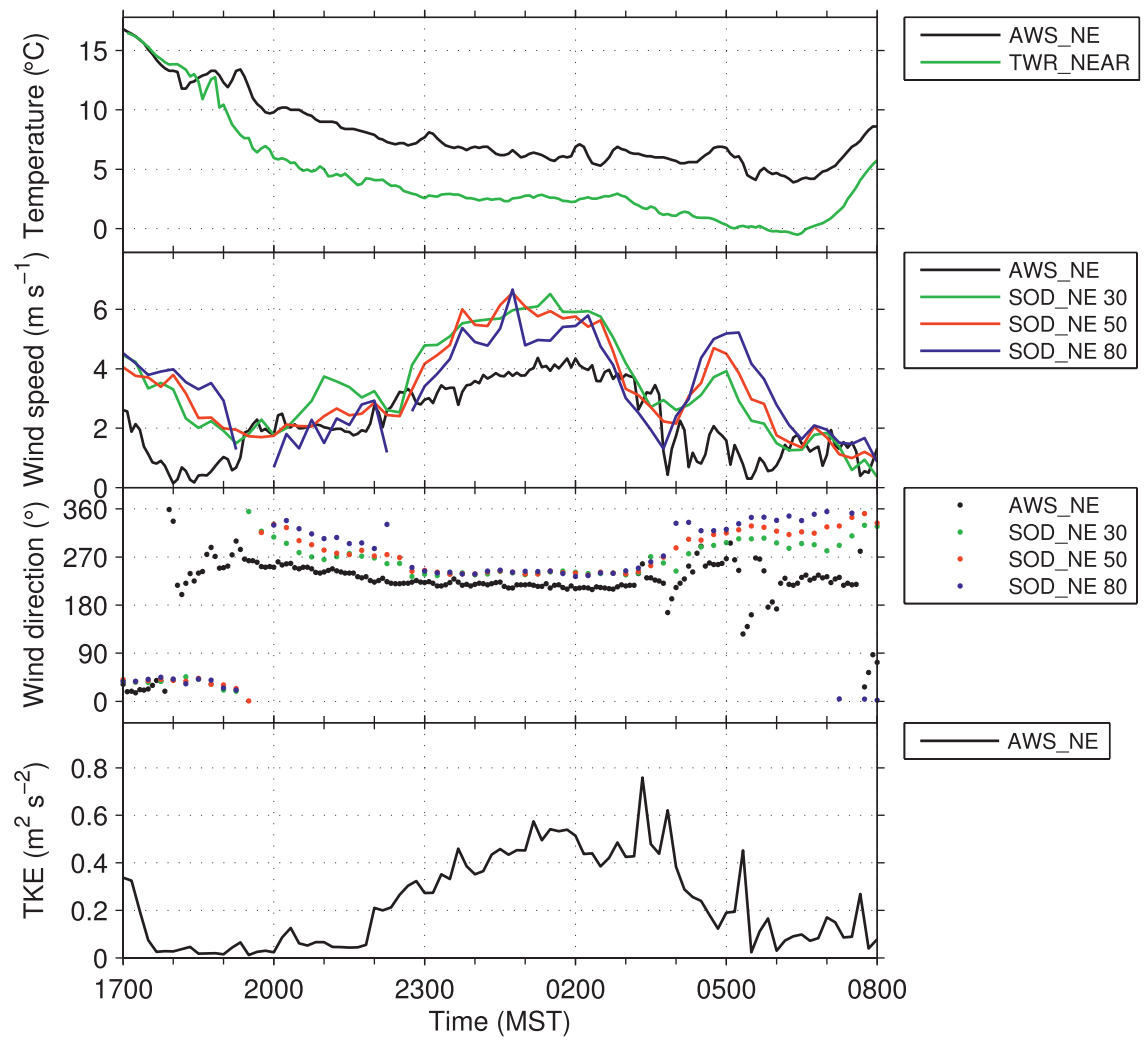

FIG. II. Near-surface temperature downstream from a surface weather station (AWS_NE) and upstream from the lowest level (3 $\mathrm{m} \mathrm{AGL)}$ of the $50-\mathrm{m}$ tower (TWR_NEAR); wind speed and direction near the surface (AWS_NE) and at 30, 50, and $80 \mathrm{~m}$ AGL (SOD_NE 30, SOD_NE 50, and SOD_NE 80) from sodar measurements downstream; and near-surface turbulent kinetic energy (TKE) downstream of the crater basin on 19-20 Oct (IOP 4). upstream conditions were similar, with a development of a surface-based inversion and a southwesterly drainage flow, small differences occurred in the strength, depth, and onset of these characteristics. The first analysis summarized in this paper points to the strength and depth of the approach flow as a key mechanism in controlling the formation and strength of DWFs, with the strongest DWFs occurring during the two IOPs with the strongest and deepest southwesterly drainage flow. The placement of multiple pressure sensors on the inner upstream crater sidewall has also made it possible to identify temporal variations in the spatial extent of DWFs. Future work will combine all of the available field measurements to determine the exact flow response in the Meteor Crater to varying upstream conditions. with extended measurements during seven IOPs. With respect to the key research questions of the METCRAX II program outlined in Table 1, the initial analysis so far has focused on the first point, that is, the upstream parameters that control the formation of DWFs. A comparison of the seven IOPs has found large variations in the strength of DWFs. While overall
The METCRAX II research program also includes a modeling component, which will look further at the formation of the DWFs at the Meteor Crater. Parametric studies are planned to investigate the necessary upstream and ambient temperature and wind conditions as well as the topographic setting to better translate the findings from the Meteor Crater to other

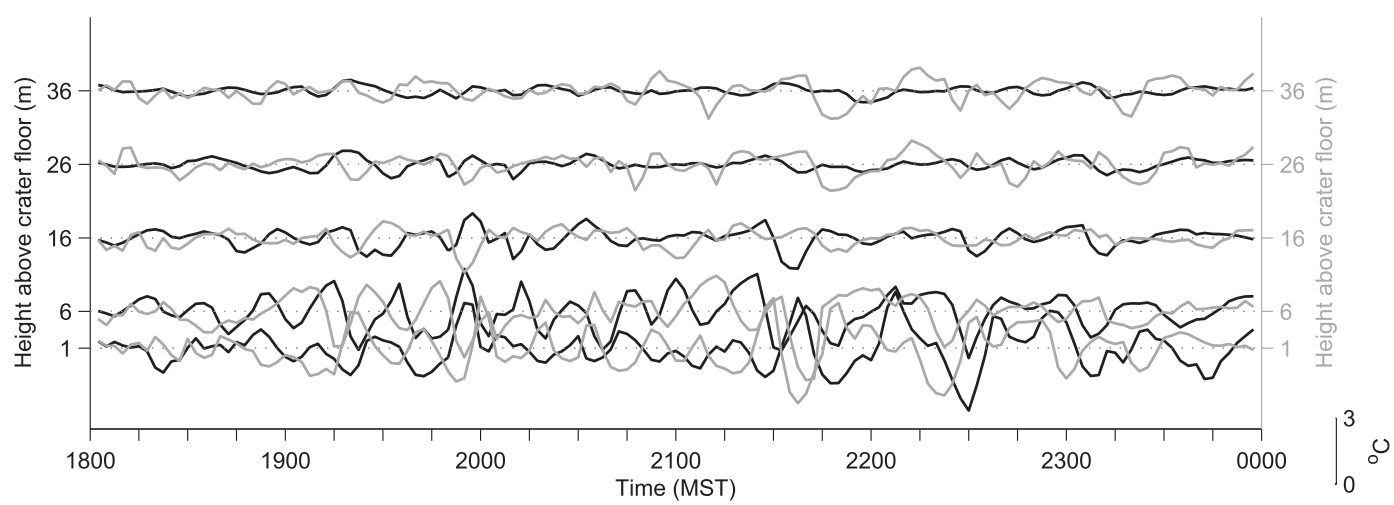

FIG. 12. Time series of filtered surface temperatures at different elevations along the northeast (black) and south-southwest (gray) sidewalls between 1800 and 0000 MST of IOP 4. 
terrain and to larger scales. While the mechanisms underlying the formation of DWFs at the Meteor Crater, that is, the interaction of a stratified flow with topography, are expected to be identical to downslope windstorms in other mountainous terrain around the world, the Meteor Crater differs in several aspects from other topography, in-

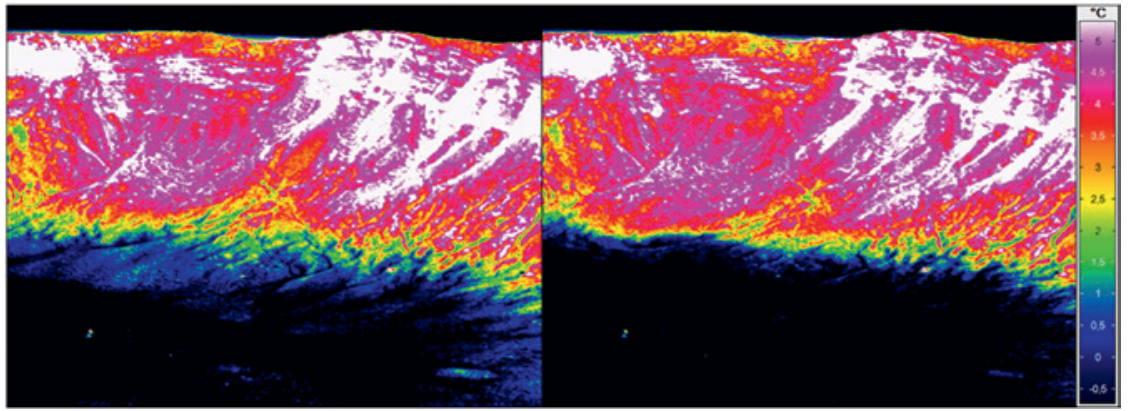

Fig. 13. Infrared images looking southwest from the north crater rim at (left) 2130 and (right) 2140 MST of IOP 4. Shading indicates ground surface temperatures. cluding its size, the strong

three-dimensionality, and the presence of the confined downstream basin. Model simulations will thus play a key role in testing the applicability of findings from METCRAX II to other terrain. While the field experiment was strongly focused on a vertical cross section through the crater from south-southwest to northnortheast, model simulations will supplement the field measurements to gain a better understanding of the three-dimensional flow field during DWF events.

The rich dataset collected during METCRAX II will also invite studies beyond the initial focus on DWFs. The field equipment placed downstream of the crater basin will be used to study the possible occurrence of wakes in the lee of the crater basin as well as differences between the upstream and downstream sides. Initial data analysis has identified oscillations in the surface temperature along the crater sidewalls, suggesting the presence of seiches in the crater-floor cold pool. Data from some of the deployed instruments will be used for testing and possibly improving measurement techniques. The lidar scanning strategies designed to visualize the lee wave in the crater (Cherukuru et al. 2015) highlight the capabilities of the dual-Doppler lidar technique. Surface temperatures from the infrared cameras will be compared to in situ temperature measurements to further improve the analysis of motions and dynamic processes in boundary layer meteorology based on thermal imagery. The possibilities of detecting the occurrence of DWFs through turbulent motions in the lee of the crater using the scintillometer will also be tested.

ACKNOWLEDGMENTS. NCAR's Earth Observing Laboratory provided equipment, field support, and data processing services. Barringer Crater Corporation (Drew Barringer, President) and Meteor Crater Enterprises, Inc. (Brad Andes, President), provided crater access, and they and their staffs provided outstanding cooperation and assistance. Bar-T-Bar Ranch and Crater Ranch LLC (Judy
Prosser) provided access to sites surrounding the crater. Dr. Eric Pardyjak at the University of Utah loaned us a tethersonde system and M. Krauß (InfraTec) loaned us infrared cameras. An additional thanks goes to M. Krauß for his technical support while we were in the field. We thank METCRAX II participants for their field and data processing assistance, including C. Arendt, P. Chilson, S. Cohn, S. Couper, C. Galli, C. Golubieski, G. Granger, J. Guard, T. Hofmann, B. Hunsaker, A. Jacques, P. Kidd, R. Klucik, K. Knudson, S. Krueger, T. Lim, N. Lucke, G. Maclean, M. Maestas, J. Militzer, J. Pechmann, S. Reddy, L. Tudor, L. Verstraete, J. Whiteman, and K. Young.

This research was supported by NSF's Physical and Dynamic Meteorology Division (B. Smull, Program Manager) through Grants AGS-1160730 (Whiteman) and AGS1160737 (Calhoun). Contribution of KIT was funded by the International Bureau of BMBF under Grant 01 DM 13002.

\section{REFERENCES}

Adler, B., C. D. Whiteman, S. W. Hoch, M. Lehner, and N. Kalthoff, 2012: Warm-air intrusions in Arizona's Meteor Crater. J. Appl. Meteor. Climatol., 51, 1010-1025, doi:10.1175/JAMC-D-11-0158.1.

Bergen, W. R., and A. H. Murphy, 1978: Potential economic and social value of short-range forecasts of Boulder windstorms. Bull. Amer. Meteor. Soc., 59, 29-44, doi:10.1175/1520-0477(1978)059<0029:PEA SVO $>2.0 . \mathrm{CO} ; 2$.

Bougeault, P., and Coauthors, 1993: The atmospheric momentum budget over a major mountain range: First results of the PYREX field program. Ann. Geophys., 11, 395-418.

- , and Coauthors, 2001: The MAP special observing period. Bull. Amer. Meteor. Soc., 82, 433-462, doi:10.1175/1520-0477(2001)082<0433:TMSOP $>2$ .3.CO;2.

Brinkmann, W. A. R., 1974: Strong downslope winds at Boulder, Colorado. Mon. Wea. Rev., 102, 592-602, 
doi:10.1175/1520-0493(1974)102<0592:SDWABC $>2.0 . \mathrm{CO} ; 2$.

Bryan, G. H., and J. M. Fritsch, 2002: A benchmark simulation for moist nonhydrostatic numerical models. Mon. Wea. Rev., 130, 2917-2928, doi:10.1175/1520 -0493(2002)130<2917:ABSFMN>2.0.CO;2.

Cherukuru, N. W., R. Calhoun, M. Lehner, S. W. Hoch, and C. D. Whiteman, 2015: Instrument configuration for dual Doppler lidar co-planar scans: METCRAX II. J. Appl. Remote Sens., 9, 096090, doi:10.1117/1.JRS.9.096090.

Clark, T. L., and W. R. Peltier, 1977: On the evolution and stability of finite-amplitude mountain waves. J. Atmos. Sci., 34, 1715-1730, doi:10.1175/1520 -0469(1977)034<1715:OTEASO>2.0.CO;2.

Durran, D. R., 1986: Another look at downslope windstorms. Part I: The development of analogs to supercritical flow in an infinitely deep, continuously stratified fluid. J. Atmos. Sci., 43, 2527-2543, doi:10.1175/1520-0469(1986)043<2527:ALADWP $>2.0 . \mathrm{CO} ; 2$.

_ 1990: Mountain waves and downslope winds. Atmospheric Processes over Complex Terrain, Meteor. Monogr., Amer. Meteor. Soc., No. 45, 59-81.

—, 2003: Downslope winds. Encyclopedia of Atmospheric Sciences, J. R. Holton, J. A. Curry, and J. A. Pyle, Eds., Elsevier, 644-650.

— winds. Part II: Nonlinear amplification beneath wave-overturning layers. J. Atmos. Sci., 44, 34023412, doi:10.1175/1520-0469(1987)044<3402:ALA DWP $>2.0 . \mathrm{CO} ; 2$.

Fritts, D. C., D. Goldstein, and T. Lund, 2010: High-resolution numerical studies of stable boundary layer flows in a closed basin: Evolution of steady and oscillatory flows in an axisymmetric Arizona Meteor Crater. J. Geophys. Res., 115, D18109, doi:10.1029/2009JD013359.

Gohm, A., G. J. Mayr, A. Fix, and A. Giez, 2008: On the onset of bora and the formation of rotors and jumps near a mountain gap. Quart. J. Roy. Meteor. Soc., 134, 21-46, doi:10.1002/qj.206.

Greeley, R., J. D. Iversen, J. B. Pollack, N. Udovich, and B. White, 1974: Wind tunnel studies of Martian aeolian processes. Proc. Roy. Soc. London, A341, 331-360, doi:10.1098/rspa.1974.0191.

Grisogono, B., and D. Belušić, 2009: A review of recent advances in understanding the meso- and microscale properties of the severe Bora wind. Tellus, 61A, 1-16, doi:10.1111/j.1600-0870.2008.00369.x.

Grubišić, V., and Coauthors, 2008: The Terrain-induced Rotor Experiment-A field campaign overview including observational highlights. Bull. Amer. Meteor. Soc., 89, 1513-1533, doi:10.1175/2008BAMS2487.1.
Haiden, T., C. D. Whiteman, S. W. Hoch, and M. Lehner, 2011: A mass flux model of nocturnal cold-air intrusions into a closed basin. J. Appl. Meteor. Climatol., 50, 933-943, doi:10.1175/2010JAMC2540.1.

Hill, M., R. Calhoun, H. J. S. Fernando, W. Wieser, D. Dörnbrack, M. Weissmann, G. Mayr, and R. Newsom, 2010: Coplanar Doppler lidar retrieval of rotors from T-REX. J. Atmos. Sci., 67, 713-729, doi:10.1175/2009JAS3016.1.

Houghton, D. D., and A. Kasahara, 1968: Nonlinear shallow fluid flow over an isolated ridge. Commun. Pure Appl. Math., 21, 1-23, doi:10.1002/cpa.3160210103.

Jackson, P. L., G. Mayr, and S. Vosper, 2012: Dynamically-driven winds. Mountain Weather Research and Forecasting, F. K. Chow, S. F. J. De Wekker, and B. Snyder, Eds., Springer, 121-218.

Katurji, M., S. Zhong, M. Kiefer, and P. Zawar-Reza, 2013: Numerical simulations of turbulent flow within and in the wake of a small basin. J. Geophys. Res. Atmos., 118, 6052-6063, doi:10.1002/jgrd.50519.

Kiefer, M. T., and S. Zhong, 2011: An idealized modeling study of nocturnal cooling processes inside a small enclosed basin. J. Geophys. Res., 116, D20127, doi:10.1029/2011JD016119.

Klemp, J. B., and D. K. Lilly, 1975: The dynamics of wave-induced downslope winds. J. Atmos. Sci., 32, 320-339, doi:10.1175/1520-0469(1975)032<0320:TD OWID>2.0.CO;2.

Kring, D. A., 2007: Guidebook to the Geology of Barringer Meteorite Crater, Arizona (aka Meteor Crater). LPI Contribution 1355, Lunar and Planetary Institute, $150 \mathrm{pp}$. [Available online at www.lpi.usra.edu /publications/books/barringer_crater_guidebook/.] Lilly, D. K., 1978: A severe downslope windstorm and aircraft turbulence event induced by a mountain wave. J. Atmos. Sci., 35, 59-77, doi:10.1175/1520 -0469(1978)035<0059:ASDWAA>2.0.CO;2.

Long, R. R., 1954: Some aspects of the flow of stratified fluids: II. Experiments with a two-fluid system. Tellus, 6, 97-115, doi:10.1111/j.2153-3490.1954.tb01100.x.

_ 1955: Some aspects of the flow of stratified fluids: III. Continuous density gradients. Tellus, 7, 341-357, doi:10.1111/j.2153-3490.1955.tb01171.x.

Magalhães, J. A., and R. E. Young, 1995: Downslope windstorms in the lee of ridges on Mars. Icarus, 113, 277-294, doi:10.1006/icar.1995.1024.

Mayr, G. J., and L. Armi, 2008: Föhn as a response to changing upstream and downstream air masses. Quart. J. Roy. Meteor. Soc., 134, 1357-1369, doi:10.1002/qj.295.

Peltier, W. R., and T. L. Clark, 1979: The evolution and stability of finite-amplitude mountain waves. Part II: Surface wave drag and severe downslope windstorms. 
J. Atmos. Sci., 36, 1498-1529, doi:10.1175/1520 -0469(1979)036<1498:TEASOF>2.0.CO;2.

Phillips, F. M., M. G. Zreda, S. S. Smith, D. Elmore, P. W. Kubik, R. I. Dorn, and D. J. Roddy, 1991: Age and geomorphic history of Meteor Crater, Arizona, from cosmogenic ${ }^{36} \mathrm{Cl}$ and ${ }^{14} \mathrm{C}$ in rock varnish. Geochim. Cosmochim. Acta, 55, 2695-2698, doi:10.1016/0016-7037(91)90387-K.

Rafkin, S. C. R., R. M. Haberle, and T. I. Michaels, 2001: The Mars Regional Atmospheric Modeling System: Model description and selected simulations. Icarus, 151, 228-256, doi:10.1006/icar.2001.6605.

Richner, H., and P. Hächler, 2012: Understanding and forecasting Alpine foehn. Mountain Weather Research and Forecasting, F. K. Chow, S. F. J. De Wekker, and B. Snyder, Eds., Springer, 219-260.

Savage, L. C., I. Crosby, S. Zhong, W. Yao, W. J. O. Brown, T. W. Horst, and C. D. Whiteman, 2008: An observational and numerical study of a regional-scale downslope flow in northern Arizona. J. Geophys. Res., 113, D14114, doi:10.1029/2007JD009623.

Smith, R. B., 1979: The influence of mountains on the atmosphere. Advances in Geophysics, Vol. 21, Academic Press, 87-230, doi:10.1016/S0065-2687(08)60262-9.

_ 1985: On severe downslope winds. J. Atmos. Sci., 42, 2597-2603, doi:10.1175/1520-0469(1985)042<2597:OS DW $>2.0 . \mathrm{CO} ; 2$.
— 1989: Hydrostatic airflow over mountains. Advances in Geophysics, Vol. 31, Academic Press, 1-41, doi:10.1016/S0065-2687(08)60052-7.

—, J. D. Doyle, Q. Jiang, and S. Smith, 2007: Alpine gravity waves: Lessons from MAP regarding mountain wave generation and breaking. Quart. J. Roy. Meteor. Soc., 133, 917-936, doi:10.1002/qj.103.

Soontiens, N., M. Stastna, and M. L. Waite, 2013: Numerical simulations of waves over large crater topography in the atmosphere. J. Atmos. Sci., 70, 1216-1232, doi:10.1175/JAS-D-12-0221.1.

Whiteman, C. D., J. M. Hubbe, and W. J. Shaw, 2000: Evaluation of an inexpensive temperature datalogger for meteorological applications. J. Atmos. Oceanic Technol., 17, 77-81, doi:10.1175/1520 -0426(2000)017<0077:EOAITD>2.0.CO;2.

— , and Coauthors, 2008: METCRAX 2006Meteorological experiments in Arizona's Meteor Crater. Bull. Amer. Meteor. Soc., 89, 1665-1680, doi:10.1175/2008BAMS2574.1.

— , S. W. Hoch, M. Lehner, and T. Haiden, 2010: Nocturnal cold-air intrusions into a closed basin: Observational evidence and conceptual model. J. Appl. Meteor. Climatol., 49, 1894-1905, doi:10.1175/2010JAMC2470.1.

\section{NEW FROM AMS BOOKS!}

\section{A Scientific Peak: How Boulder Became a World Center for Space and Atmospheric Science}

\section{Joseph P. Bassi}

nce a Wild West city tucked between the Rocky Mountains and the Great Plains, Boulder is now home to some of the biggest names in science, including NCAR, NOAA, and NIST.

Why did big science come to Boulder? How did Boulder become the research mecca it is today?

A Scientific Peak is a fascinating history that introduces us to a wide variety of characters, such as Walter Orr Roberts, and the serendipitous brew of politics, passion, and sheer luck that, during the post-WWII and Cold War eras, transformed this "scientific Siberia" into one of America's smartest cities.

(C) 2015, 264 pages, paperback

print ISBN: 978-1-935704-85-0 eISBN: 978-1-940033-89-1 List price: $\$ 35$ AMS Member price: $\$ 25$

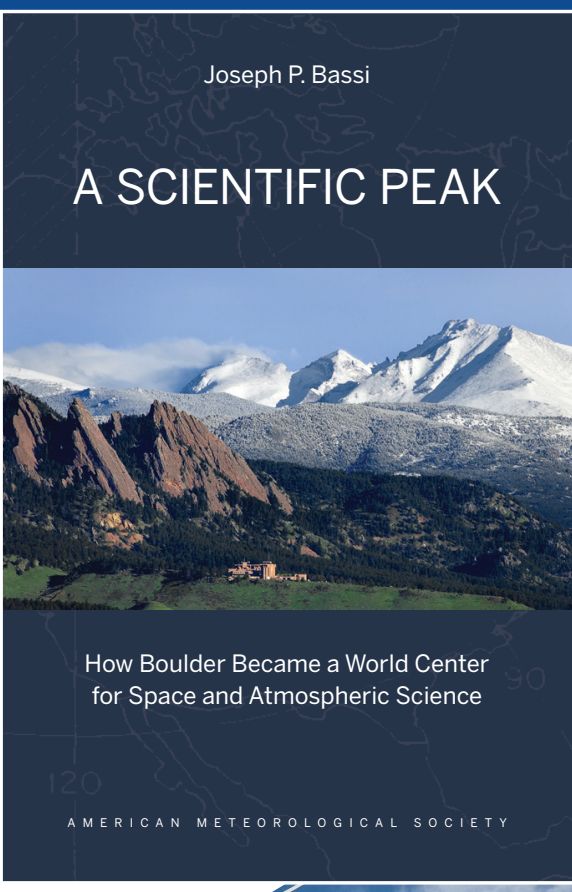




\section{Science at Your Fingertips}

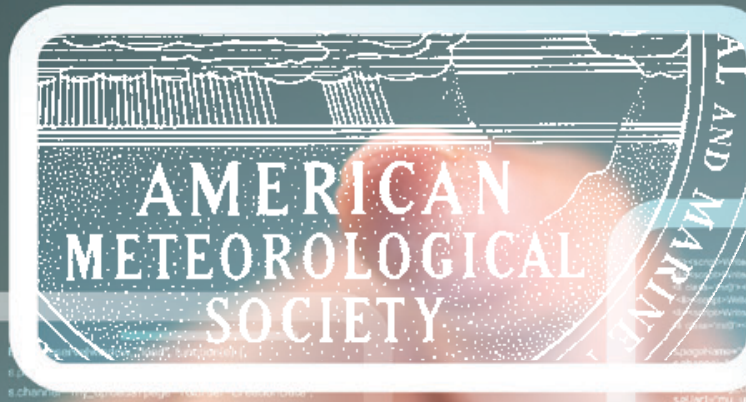

AMS Journals are now optimized for viewing on your mobile device.

Access journal articles, monograph titles, and BAMS content using your iOS, Android, or Blackberry phone, or tablet.

Features include:

- Saving articles for offline reading

- Sharing of article links via email and social networks

- Searching across journals, authors, and keywords

And much more...

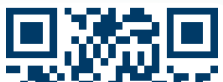
\%tri 마. 直社
Scan code to connect to journals.ametsoc.org 